\title{
PENERAPAN PEMBELAJARAN TEMATIK UNTUK MENINGKATKAN AKTIVITAS BELAJAR SISWA MELALUI PEMANFAATAN SUMBER BELAJAR DI SEKOLAH DASAR
}

\author{
Nur Hasanah ${ }^{2}$ \\ Surel : dedenurhasanah103@gmail.com
}

\begin{abstract}
Abstrak
Penelitian ini bertujuan untuk memperoleh informasi dan mendeskripsikan peningkatan aktivitas belajar siswa melalui pemanfaatan sumber belajar dengan melihat aspek fisik, mental, dan emosional melalui penerapan pembelajaran tematik. Metode penelitian yang digunakan adalah metode deskriptif. Bentuk penelitian yaitu Penelitian Tindakan Kelas (Classroom Action Research) serta bersifat kolaboratif. Penelitian berlangsung di SDN 036 Balai Jaya.Subyek penelitian adalah peserta didik kelas III yang berjumlah 33 orang dan 1 guru kelas. Teknik pengumpulan data yang digunakan adalah observasi langsung dan pencermatan dokumen, yang diamati berupa kemampuan guru merencanakan dan melaksanakan pembelajaran, serta aktivitas belajar peserta didik. Penelitian ini dilakukan dalam 2 siklus dengan hasil akhir penelitian yang diperoleh yaitu pada siklus I aktivitas fisik 84,08\%, aktivitas mental 94,59\%, dan aktivitas emosional 94,59\%. Pada siklus II aktivitas fisik 93,09\%, aktivitas mental 91,89\%, dan aktivitas emosional 97,29\%. Dari data yang diperoleh dapat disimpulkan bahwa terjadi peningkatan aktivitas belajar peserta didik dengan menerapkan pembelajaran tematik.
\end{abstract}

Kata Kunci:pembelajaran tematik, aktivitas belajar, sumber belajar

\section{PENDAHULUAN}

Dewasa ini banyak kita jumpai berbagai macam sumber belajar yang dapat digunakan baik dalam dunia pendidikan maupun non-pendidikan khususnya masyarakat Indonesia yang semakin hari semakin memperbanyak wawasannya dengan kemajuan teknologi pada saat sekarang ini. Keberadaan sumber belajar menjadi pendorong utama dalam meningkatkan aktivitas siswa dalam belajar.

${ }^{2}$ PENDIDIKAN DASAR PASCASARJANA UNIMED 
Dengan demikian sumber belajar juga mempengaruhi hasil belajar anak baik di sekolah maupun di lingkungan rumah atau masyarakat.

Namun pada kenyataannya masih banyak para siswa yang kurang mengetahui keberadaan sumber belajar serta pemanfaatannya dalam dunia pendidikan. Mereka hanya beranggapan sumber belajar hanya bisa didapatkan dari buku, majalah, koran atau hanya mengharapkan apa yang diberikan oleh para pendidik. Padahal dalam pembelajaran tematik keberadaan sumber belajar menjadi landasan utama untuk meningkatkan aktivitas siswa dalam pembelajaran. Dikarenakan dengan sumber belajar yang memadai maka kita sebagai pendidik menyadari akan pentingnya sumber belajar tersebut dalam peningkatan dan hasil belajar anak disetiap jenjang yang ada di sekolah.

Hal ini hendaknya menjadi perhatian bagi para pendidik untuk mencari sumber belajar yang benar-benar memadai dan sesuai dengan keadaan lingkungan disekolah maupun masyarakat dalam upaya meningkatkan aktivitas belajar siswa dalam pembelajaran tematik. Permasalahan ini tidak terlepas dari tanggung jawab para guru untuk terus meningkatkan aktivitas belajar siswa dalam pembelajaran tematik serta kemampuan guru dalam pemanfaatan sumber belajar.

Berdasarkan hal tersebut peran guru dan siswa dalam pemanfaatan sumber belajar sangat penting dalam meningkatkan aktivitas belajar siswa dalam pembelajaran tematik. Tentunya, untuk merealisasikan hal tersebut perlu adanya kerjasama yang baik dalam memperoleh sumber belajar dan pengetahuan dalam pemanfaatan sumber belajar tersebut.Dalam keseluruhan upaya pendidikan, proses pembelajaran tematik merupakan salah satu pembelajaran yang dirancang khusus berdasarkan tema-tema tertentu. Dalam pembahasannya tema tersebut ditinjau dari berbagai mata pelajaran. Tidak mudah memang dalam penggunaan pembelajaran tematik dikarenakan guru harus benar-benar mempersiapkan segala sumber belajar yang sesuai dengan tema pembelajaran setiap harinya guna meningkatkan aktivitas belajar siswa di sekolah.

Hal ini dikarenakan dalam proses pembelajaran tematik lebih menekankan pada contoh yang benar-benar kompleks sehingga mempermudah siswa dalam memahami pembelajaran. Hal demikian menunjukkan bahwa semua pihak terlibat dalam setiap kegiatan pembelajaran baik dalam hal sumber belajar, aktivitas siswa maupun pemahaman akan pembelajaran tematik.Sumber-sumber belajar tersebut jika dimanfaatkan dan dikelola dengan baik akan membantu kelancaran dalam proses pembelajaran, akan tetapi banyak para guru yang tidak menyadari bahkan tidak sedikit yang mengabaikan pentingnya sumber belajar dalam proses pembelajaran, meskipun sudah diketahui bahwa sumber belajar adalah komponen penting dalam pembelajaran yang sangat menunjang aktivitas belajar siswa dalam pembelajaran tematik.

Menurut Sudjana dan Rivai (dalam Jarmono) sumber belajar adalah segala yang dapat dimanfaatkan guna memberi kemudahan seseorang dalam belajar. 
Adapun yang dimaksud pemanfaatan sumber belajar dalam penelitian ini adalah suatu upaya untuk mendayagunakan segala yang dapat dimanfaatkan untuk memberi kemudahan seseorang dalam belajar. Dengan sumber belajar yang ada diharapkan dapat tercipta kemampuan mendidik anak dengan cara-cara yang menyenangkan sehingga dapat memiliki dampak positif dalam diri anak yaitu selalu meningkatkan keinginan untuk belajar.

Menurut Rumidani, dkk. "Pembelajaran tematik dimaknai sebagai pembelajaran yang dirancang berdasarkan tema-tema tertentu". Dalam pembahasannya tema tersebut ditinjau dari berbagai mata pelajaran. Pembelajaran tematik mengintegrasikan materi beberapa mata pelajaran dalam satu tema atau topik pembahasan. Sedangkan menurut Slekar (dalam Ain dan Maris) pembelajaran tematik adalah suatu model terapan pembelajaran terpadu yang mengintegerasikan beberapa mata pelajaran dalam satu kesatuan yang terikat oleh tema.

Menurut Zulanda, dkk "Aktivitas belajar adalah segala kegiatan yang melibatkan peserta didik dalam proses pembelajaran guna mencapai tujuan belajar". Adapun kegiatan yang melibatkan peserta didik yaitu peserta didik mengamati atau menggunakan media, mengerjakan tugas, melakukan demonstrasi, memecahkan masalah, berani mengungkapkan pendapat, berani tampil kedepan kelas, dan antusias dalam proses pembelajaran.

\section{METODE PENELITIAN}

Penelitian berlangsung di Sekolah Dasar Negeri 036 Balai Jaya, subyek penelitian adalah peserta didik kelas III yang berjumlah 33 peserta didik dan guru kelas. Teknik pengumpulan data yang digunakan adalah teknik observasi langsung dan teknik pencermatan dokumen dengan alat pengumpul data yaitu lembar pengamatan untuk kemampuan guru merencanakan dan melaksanakan pembelajaran serta aktivitas peserta didik. Prosedur dalam penelitian ini terdiri dari 4 tahap, yaitu: (1) Tahap perencanaan tindakan, (2) Tahap pelaksanaan tindakan, (3) Tahap observasi, dan (4) Tahap refleksi.

Pada tahap perencanaan tindakan, peneliti bekerjasama dengan guru kolaborasi untuk merencanakan tindakan, antara lain: (1) menganalisis kurikulum beberapa mata pelajaran, yaitu Seni Budaya dan Keterampilan (SBK), Pendidikan Jasmani (Penjas), Bahasa Indonesia, dan Matematika untuk mengetahui Standar Kompetensi dan Kompetensi Dasar yang akan dihubungkan antara mata pelajaran yang satu dengan yang lainnya; (2) membuat Rencana Pelaksanaan Pembelajaran (RPP); (3) mempersiapkan materi dan media pembelajaran; (4) menentukan teknik penelitian; (5) mengalokasikan waktu. Pada tahap pelaksanaan tindakan, penelitian atau pelaksanaan tindakan ini dilaksanakan pada semester ganjil, mengadakan kolaborasi bersama guru kelas III. Banyaknya pertemuan dilaksanakan setiap siklusnya 2 kali pertemuan $(2 \mathrm{x}$ pertemuan $=1$ siklus $)$. Setiap 
satu kali pertemuan alokasi waktu 5 jam pelajaran atau selama 175 menit. Pada tahap kegiatan pengamatan dilakukan pada saat pelaksanaan tindakan siklus oleh guru kelas dengan menggunakan lembar pengamatan. Tujuannya adalah untuk melihat sejauh mana keberhasilan pelaksanaan tindakan yang telah dilakukan. Tahap terakhir yaitu refleksi, berdasarkan data yang diperoleh dari hasil observasi langsung dan hasil pencermatan dokumen pada setiap siklus, maka bersama dengan guru kolaborasi melakukan refleksi dari tindakan yang telah dilakukan selama proses pembelajaran setiap siklusnya. Setelah mengetahui kelebihan dan kekurangan dalam pelaksanaan pembelajaran, maka akan direncanakan kembali tindakan yang akan dilakukan untuk memperbaiki kekurangan yang ada, kemudian diperbaiki pada siklus berikutnya.

\section{HASIL PENELITIAN DAN PEMBAHASAN}

Pada siklus I tema yang digunakan sumber belajar buku. Pada tahap pelaksanaan kegiatan pembelajaran dapat dipaparkan dalam paragrap berikut. Kegiatan awal pembelajaran dimulai dengan salam pembuka, doa, dan mengecek kehadiran peserta didik. Kegiatan berikutnya adalah apersepsi, guru bertanya kepada peserta didik "Anak-anak, kita sekolah membawa apa saja? Di sekolah kita menulis menggunakan apa saja? Nah, bagaimana kalau hari ini kita belajar mengetahui apa saja yang ada di dalam buku, setuju anak-anak?". Selanjutnya guru menyampaikan informasi tujuan dan kegiatan pembelajaran. Kemudian sebelum pelajaran dimulai, guru mengkondisikan kelas terlebih dahulu.

Kegiatan inti terdiri dari eksplorasi, elaborasi, dan konfirmasi. Dalam tahap eksplorasi, kegiatan pembelajaran dilakukan tanya jawab dengan peserta didik mengenai kegiatan apa saja yang dilakukan disekolah. Kemudian peserta didik menyanyikan lagu "pergi sekolah" bersama-sama dengan menggunakan audio. Pada tahap eksplorasi ini peserta didik mulai fokus dalam pembelajaran, hal ini dikarenakan peserta didik mengeksplorasikan pengalamannya dalam mengamati gambar-gambar apa saja yang ada di dalam buku pelajaran. Dalam kesempatan ini juga peserta didik berani mengemukakan pendapatnya dari pertanyaan-pertanyaan guru berdasarkan gambar tersebut. Pada tahap elaborasi, peserta didik menyebutkan contoh-contoh apa saja yang ada di dalam buku. Selain itu, peserta didik diajak untuk bermain dengan menggunakan metodenumber head together. Masing-masing peserta didik mendapatkan kartu bernomor dan kartu tersebut ditempel di dahi mereka. Kemudian peserta didik membaca buku. Setelah itu, peserta didik yang dipanggil nomornya oleh guru ke depan kelas membacakan ulang. Dari bacaan tersebut, peserta didik diminta untuk mengamati setiap isi buku dan apa saja yang ada di dalam isi buku tersebut. Kemudian peserta didik berkompetisi menyebutkan apa saja yang berkaitan di dalam buku tersebut. Selanjutnya tahap konfirmasi merupakan tahap kegiatan inti yang terakhir. Adapun tindakan yang dilakukan guru dalam pembelajaran adalah guru 
mengumumkan peserta didik yang menjadi pemenang dalam berkompetisi dan memberikan umpan balik positif dan penguatan dalam bentuk lisan, isyarat maupun hadiah terhadap keberhasilan peserta didik. Selanjutnya guru memberikan motivasi kepada peserta didik yang kurang atau belum berpartisipasi aktif dalam pembelajaran.

Dalam kegiatan akhir dari pembelajaran peserta didik dengan bimbingan guru menyimpulkan materi pelajaran dan dilanjutkan dengan mengevaluasi pembelajran melalui soal evaluasi untuk mengetahui ketercapaian tujuan pembelajaran. Hasil evaluasi diberikan tindak lanjut, yaitu meminta peserta didik yang belum menguasai materi pelajaran untuk mengulangi kembali pelajarandirumah. Kemudian guru menginformasikan materi selanjutnya dan diakhiri dengan salam penutup.

Pada siklus II peneliti bersama guru kolaborator melakukan perencanaan pembelajaran untuk siklus II. Fokus perencanaan pada siklus II ini adalah untuk memperbaiki kekurangan-kekurangan yang terjadi pada siklus I, seperti aktivitas fisik seperti pada saat membaca masih ada peserta didik yang mengganggu temannya, aktivitas emosional seperti peserta didik kurang percaya diri untuk bercerita didepan kelas. Pada kegiatan awal pembelajaran dimulai dengan salam pembuka, doa, dan memeriksa kesiapan peserta didik belajar yaitu mencakup aspek mengecek kehadiran, kerapian, ketertiban, perlengkapan belajar, dan kesiapan belajar peserta didik. Kegiatan berikutnya adalah apersepsi, guru bertanya kepada peserta didik mengenai “Anak-anak, apakah kalian dirumah mempunyai majalah atau koran? Siapa yang suka membaca majalah atau koran? Nah, bagaimana kalau hari ini kita belajar membaca koran dan majalah, setuju anak-anak?". Kemudian menyampaikan informasi tujuan dan kegiatan pembelajaran. Sebelum pelajaran dimulai, guru mengkondisikan kelas terlebih dahulu.

Kegiatan inti, terdiri dari eksplorasi, elaborasi, dan konfirmasi. Dalam tahap eksplorasi, kegiatan pembelajaran dilakukan tanya jawab dengan peserta didik mengenai majalah apa yang mereka sukai. Kemudian peserta didik menyanyikan lagu "binatang” bersama-sama dengan menggunakan audio. Dalam kesempatan ini juga peserta didik berani mengemukakan pendapatnya dari pertanyaan-pertanyaan yang diajukan oleh guru. Tahap elaborasi, dalam tahap ini peserta didik menyebutkan apa saja binatang yang diketahui. Selain itu juga peserta didik diajak untuk bermain dengan menggunakan metode number head together. Masing-masing peserta didik mendapatkan kartu bernomor dan kartu tersebut ditempel di dahi mereka. Kemudian peserta didik mendengarkan cerita tentang "gajah". Setelah itu, peserta didik yang dipanggil nomornya oleh guru ke depan kelas menceritakan kembali cerita tersebut. Dari cerita tersebut, peserta didik diminta untuk menggambar dan mengamati gambar. Peserta didik juga 
kedepan kelas menunjukkan gambar gajah tersebut. Kemudian peserta didik diajak untuk bermain dengan menggunakan metode snowball throwing. Peserta didik menggilirkan sebuah bola sambil bernyanyi. Ketika lagu sudah habis dan bola berhenti kepeserta didik yang lain, peserta didik tersebut kedepan kelas bersama teman sebangkunya untuk berkompetisi mengelompokkan mainan-mainan yang berbentuk bangun datar. Tahap konfirmasi, adapun tindakan yang dilakukan guru dalam pembelajaran adalah guru mengumumkan peserta didik yang menjadi pemenang dalam berkompetisi dan memberikan penguatan dalam bentuk lisan, isyarat maupun hadiah terhadap keberhasilan peserta didik. Selanjutnya guru memberikan motivasi kepada peserta didik yang belum berpartisipasi aktif dalam pembelajaran.

Dalam kegiatan akhir dari pembelajaran peserta didik dengan bimbingan guru menyimpulkan materi pelajaran dan dilanjutkan dengan mengevaluasi pembelajran melalui soal evaluasi untuk mengetahui ketercapaian tujuan pembelajaran. Hasil evaluasi diberikan tindak lanjut, yaitu meminta peserta didik yang belum menguasai materi pelajaran untuk mengulangi kembali belajar dirumah. Kemudian guru menginformasikan materi selanjutnya dan diakhiri dengan salam penutup.

Berikut ini data yang diperoleh dalam penelitian berupa hasil lembar pengamatan kemampuan guru dalam melaksanakan pembelajaran dan aktivitas belajar peserta didik. Pada siklus I, yaitu: (1) rata-rata peserta didik yang melakukan aktivitas fisik sesuai indikator yang diamati dalam proses pembelajaran mencapai $84,08 \%$, (2) rata-rata peserta didik yang melakukan aktivitas mental sesuai indikator yang diamati dalam proses pembelajaran mencapai 94,59\% dari seluruh peserta didik, (3) rata-rata peserta didik yang melakukan aktivitas emosional sesuai indikator yang diamati dalam proses pembelajaran mencapai $94,59 \%$.

Sedangkan pada siklus II, yaitu: (1) rata-rata peserta didik yang melakukan aktivitas fisik sesuai indikator yang diamati dalam proses pembelajaran mencapai $93,09 \%$, (2) rata-rata peserta didik yang melakukan aktivitas mental sesuai dengan indikator yang diamati dalam proses pembelajaran mencapai 97,29\%, (3) rata-rata peserta didik yang melakukan aktivitas emosional sesuai indikator yang diamati dalam proses pembelajaran mencapai 97,29\%. Dengan demikian, selisih peningkatan yang terjadi dari siklus I ke siklus II pada aktivitas fisik sebesar 9,01\%, aktivitas mental sebesar 2,7\%, dan aktivitas emosional sebesar 2,7\%.

\section{SIMPULAN}

Berdasarkan data-data yang diperoleh dari hasil penelitian yang telah dilakukan, maka aktivitas belajar peserta didik dengan menerapkan pembelajaran tematik di kelas III Sekolah Dasar Negeri 036 Balai Jaya dapat dinyatakan meningkat dengan baik. Hal ini dapat dilihat dari indikator kinerja aktivitas belajar 
dengan memperhatikan berbagai indikator aktivitas fisik, mental dan emosional dapat diuraikan sebagai berikut, yaitu: (1) terdapat peningkatan aktivitas fisik peserta didik kelas III dengan menerapkan pembelajaran tematik pada siklus I dan II, (2) terdapat peningkatan aktivitas mental peserta didik di kelas III dengan menerapkan pembelajaran tematik pada siklus I dan II, (3) terdapat peningkatan aktivitas emosional peserta didik kelas III dengan menerapkan pembelajaran tematik pada siklus I dan II.

\section{DAFTAR RUJUKAN}

Ain, Nurul dan Maris Kurniawati. Implementasi Kurikulum KTSP: Pembelajaran Tematik di Sekolah Dasar. Malang: Jurnal Inspirasi Pendidikan Universitas Kanjuruhan Malang.

Jarmono. 2016. Pemanfaatan Sumber Belajar Dalam Pembelajaran Pendidikan Agama Islam di SD Negeri 1 Logasari Kecamatan Rembang Kabupaten Purbalingga. Purwekerto: IAIN Purwekerto.

Rumidani, dkk. 2014. Implementasi Pembelajaran Tematik Berbasis Lingkungan Untuk Meningkatkan Motivasi dan Hasil Belajar Calistung Siswa Sekolah Dasar. Jurnal Pascasarjana Universitas Pendidikan Ganesha. Vol 4.

Zulanda, dkk. Penerapan Pembelajaran Tematik Untuk Meningkatkan Aktivitas Belajar Peserta Didik di Sekolah Dasar. Jurnal Pendidikan Guru Sekolah Dasar. 
